\title{
Effects of transport stress on physiological responses and milk production in lactating dairy cows
}

\author{
Heeok Hong ${ }^{1}$, Eunchae Lee ${ }^{2}$, In Hyung Lee ${ }^{2}$, and Sang-Rak Lee ${ }^{2, *}$
}

* Corresponding Author: Sang-Rak Lee Tel: +82-2-450-3696, Fax: +82-2-458-2124,

E-mail: leesr@konkuk.ac.kr

'Department of Medical Science, Konkuk University School of Medicine, Seoul 05029, Korea

${ }^{2}$ Department of Animal Bioscience and Technology, Konkuk University, Seoul 05029, Korea

ORCID

Heeok Hong

https://orcid.org/0000-0001-6315-7097

Eunchae Lee

https://orcid.org/0000-0003-0143-4022

In Hyung Lee

https://orcid.org/0000-0001-7182-8671

Sang-Rak Lee

https://orcid.org/0000-0002-8905-0770

Submitted Feb 6, 2018; Revised Apr 16, 2018; Accepted Aug 8, 2018
Objective: This study was conducted to investigate the effect of transport stress on physiological and hematological responses and milk performance in lactating dairy cows.

Methods: Ten lactating dairy cows were randomly divided into 2 groups. The treatment group (TG) was transported $200 \mathrm{~km}$ for $4 \mathrm{~h}$ by truck, and the control group (NTG) was restrained by stanchion for $4 \mathrm{~h}$ in Konkuk University farm. Blood and milk samples were collected at $24 \mathrm{~h}$ pre-transport; 1, 2, and $4 \mathrm{~h}$ during transport; and 2, 24, and $48 \mathrm{~h}$ post-transport. Milk yields were measured at $24 \mathrm{~h}$ pre-transport, $0 \mathrm{~h}$ during transport, and 24,48 , and $72 \mathrm{~h}$ post-transport.

Results: Leukocyte, neutrophil, and monocyte numbers in the TG were significantly higher than those of the NTG at each experimental time point. Lymphocyte numbers in the TG were significantly $(\mathrm{p}<0.05)$ higher than those of the NTG at $48 \mathrm{~h}$ post-transport. Additionally, the neutrophil:lymphocyte ratio of the TG was $45 \%$ and $46 \%$ higher than that of the NTG at $4 \mathrm{~h}$ during transport and $2 \mathrm{~h}$ post-transport, respectively. There were no significant differences in erythrocyte numbers, hemoglobin concentrations, platelet numbers, and hematocrit percentages between two groups. Cortisol levels in the TG were significantly $(\mathrm{p}<0.05)$ higher than those in the NTG. Milk yields in the TG were lower than those in the NTG. The somatic cell count (SCC) of the TG was significantly $(\mathrm{p}<0.05)$ higher than that of the NTG at 1 and $2 \mathrm{~h}$ during transport; that of the TG increased dramatically at $1 \mathrm{~h}$ during transport and gradually decreased subsequently.

Conclusion: Transport stress increased blood parameters including leucocyte, neutrophil, and monocyte numbers by increased cortisol levels, but did not affect erythrocytes, hemoglobin and hematocrit levels. Additionally, transport resulted in a decrease in milk yield and reduced milk quality owing to an increase in milk SCC.

Keywords: Transport Stress; Physiological Response; Hematological Responses; Milk Production

\section{INTRODUCTION}

One of the stressors that livestock animals receive is owing to transport. Transport of livestock may expose animals to physical stimuli such as altered external conditions or changes in temperature, physiological stimuli such as restriction of feed and water during transport, and psychological stimuli due to exposure to new environments [1]. Changes in the environment during transport stimulate emotions and lead to physical fatigue, resulting in physiological changes in livestock. Thus, transport is considered to be a cause of discomfort and stress in livestock [2-4]. In addition, the lack of post-transit facilities and inadequate feed and water supply can also lead to post-transport stress [5]. These stresses have negative consequences for the health of livestock such as changes in biochemical function, endocrine balance, and pathological variables, and can sometimes even lead to death [6,7]. The stress response consists of the action of the hypothalamic-sympathetic nervous system and the hypothalamic-pituitary- 
adrenal (HPA) axis. The hypothalamus-sympathetic nervous system recognizes external stressors via signals in the cerebral cortex and secretes catecholamines, such as epinephrine and norepinephrine, in the adrenal medulla and brain [8-10]. The action of HPA is mediated by corticotrophin-releasing factor produced by the paraventricular nucleus in the hypothalamus, which leads to the secretion of $\beta$-endorphin and adrenocorticotropic hormone (ACTH). This ACTH leads to secretion of glucocorticoids in the adrenal cortex, which has negative effects on livestock [9]. While research has been carried out on the physiological and behavioral changes in ruminant livestock owing to stress after transport, most of these studies have been carried out on young calves and cattle. In particular, there are few studies on the changes in physiology and productivity in milking cattle. Hence, the present study was conducted to investigate the physiological changes caused by transport stress and the changes in milk yield and milk composition of lactating dairy cows to provide fundamental data for improving the welfare of livestock and promoting milk production.

\section{MATERIALS AND METHODS}

\section{Animals}

Ten non-pregnant, clinically healthy Holstein lactating dairy cows (average age 41 months, $523.8 \mathrm{~kg}, 1.5$ parity number, 123 days in milk, milk yield $34 \mathrm{~kg}$ ) were used. The cows were provided free access to feed and water which were supplied at 10:00 AM daily. The feed used in this study was a total mixed ration (TMR) which was composed of alfalfa, ryegrass straw, cottonseed, beet pulp, and commercial concentrates.

The cows had no history of mastitis or peripartum disease and had no previous experience of road transport. This study conformed to the Guide for the Care and Use of Laboratory Animals published by the US National Institutes of Health (NIH publication No. 85-23, revised 1996, latest revision in 2011) and was approved by the Konkuk University Animal Welfare Committee (KU 09021).

\section{Transport}

The cows were randomly divided into two groups-a transported group (TG, $\mathrm{n}=5$ ) and a non-transported group (NTG, $\mathrm{n}=5$ ). TG cows were loaded three and two heads separately, fixing heads with polypropylene rope of $8 \mathrm{~mm}$ diameter in two uncovered trucks ( $2.2 \times 6.5 \mathrm{~m}$, wood flooring) exclusively used for livestock transport. The trucks were equipped with iron guardrails and returned to the point of departure after transport for $4 \mathrm{~h}$ at an average speed of $50 \mathrm{~km} / \mathrm{h}$ on an asphalt paved road. Blood and milk samples were collected from the cows in trucks stopped for 15 min during transport at 1,2, and $4 \mathrm{~h}$. Temperature and relative humidity during the transport period were average $3.3^{\circ} \mathrm{C}$ and $76.9 \%$, respectively. No accidents occurred during the transport period. TG cows could be not fed TMR and water during transport, but all cows included in the NTG were confined to a pen where they were fed TMR and water after the $4 \mathrm{~h}$ transport. The NTG cows were housed in a pen with iron stanchions at the experimental farm as the points of departure and destination under the same feeding conditions as those for the TG cows.

\section{Sample collection}

Blood samples were collected via jugular venipuncture by a veterinarian. Two $3 \mathrm{~mL}$ blood samples of all cows were collected into evacuated tubes containing ethylenediaminetetraacetic acid $\mathrm{K}_{2}$ or clot activator; blood samples were collected pretransport and during transport $(-24,0,1,2$, and $4 \mathrm{~h})$ and post-transport $(+2,+24$, and $+48 \mathrm{~h})$ from cows in trucks and individual pens, as shown in Figure 1. Next, milk samples were collected pre-transport and during transport $(-24,0,1$, 2 , and $4 \mathrm{~h})$ and post-transport $(+2,+24,+48 \mathrm{~h})$ from four teats using hands. Before the milk sample collection, the teat was washed once with a wet towel and the water was completely removed with a dry towel, and the teat was disinfected with $70 \%$ alcohol. And then the first milk was thrown out and milk samples were collected in more than $15 \mathrm{~mL}$ per teat using 50 $\mathrm{mL}$ conical tube. After mixing four samples, $15 \mathrm{~mL}$ of this mixture was collected to use as the milk sample for the assay. All

\section{Time of experimental period}

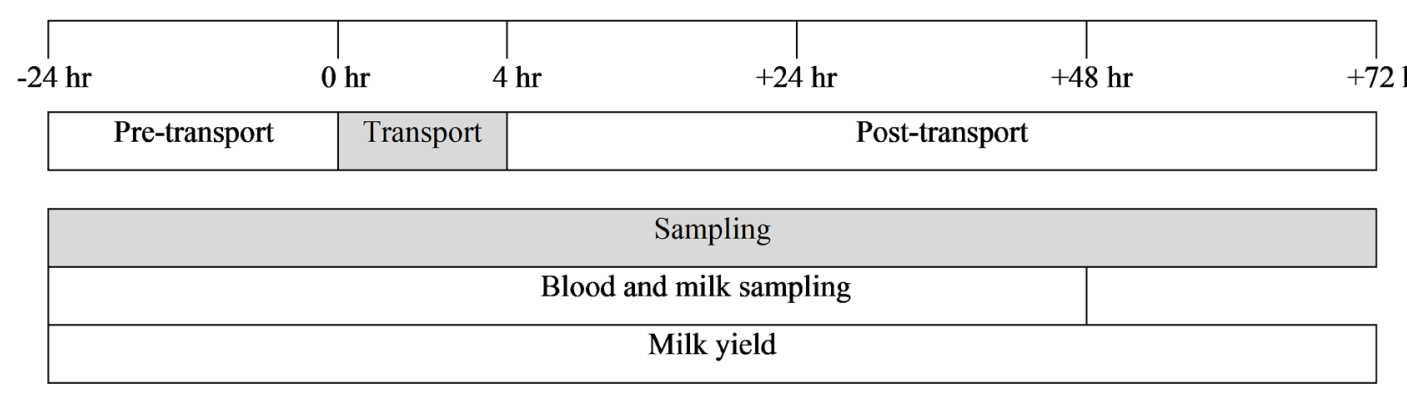

Figure 1. Schematic diagram of the experiment. Blood and milk samples were collected 7 times: pre-transport ( $-24 \mathrm{~h})$, during transport $(1,2,4 \mathrm{~h})$, and post-transport (+2, $+24,+48$ h). Milk yields were measured every morning for 4 days. 
samples were placed on ice and immediately transferred to the laboratory for analysis. Blood samples for cortisol measurement were centrifuged at $3,000 \times g$ for $20 \mathrm{~min}$ at $4^{\circ} \mathrm{C}$ to obtain the serum samples. The supernatants were stored in microtubes. All samples were immediately frozen at $-80^{\circ} \mathrm{C}$ and stored at $-80^{\circ} \mathrm{C}$ until analysis. Milk yields were measured every morning for 4 days using a milking equipment (Dematron 70, Westfaliasurge, Düsseldorf, Germany) as shown in Figure 1.

\section{Blood and milk analysis}

The white blood cell count and number of neutrophil, lymphocyte, monocyte, eosinophil, basophil, and red blood cells in the blood samples were measured using an automatic analyzer (Hemavet 850FS, CDCtech, Oxford, CT, USA). Hemoglobin levels were measured using an automated coulter analyzer (STKS, Instrumentation Laboratories, Bedford, MA, USA). Concentrations of milk fat, protein, lactose, solids-not-fat, and milk urea nitrogen were measured using Milkoscan FT 6000 (Foss Electric A/S, Hiller, Denmark). Somatic cell count (SCC) was analyzed using Fossomatic 5000 counter (Foss Electric Co., Hillerød, Denmark).

\section{Cortisol measurements}

Serum cortisol concentrations were determined using 1470 Wizard (Perkin Elmer, Turku, Finland) that uses the antibodycoated tube method of radioimmunoassay.

\section{Statistical analysis}

The data in each group were statistically compared using TTEST in Statistical Analysis System (SAS Institute, Cary, NC, USA, 2002). Significant differences between the TG and NTG were analyzed using Student t-test. Significant differences between pre-transport $(-24 \mathrm{~h})$ and during and post-transport $(0,1,2,4,+2,+24,+48,+72 \mathrm{~h})$ in both groups were analyzed using paired t-test.

\section{RESULTS}

Effects of transport stress on white blood cell and differential counts in lactating cows

As shown in Figure 2A, the white blood cell count of the TG was significantly $(p<0.05)$ higher than those of the NTG for each experimental time (pre- transport, transport, and posttransport). In the TG, the white blood cell counts at $4 \mathrm{~h}$ transport and $2 \mathrm{~h}$ post-transport were $17.46 \pm 1.65$ and $18.72 \pm 1.47 \times 10^{3} / \mu \mathrm{L}$, respectively. These values were significantly $(\mathrm{p}<0.05)$ higher by $31.7 \%$ and $41.2 \%$, respectively, compared to those seen at $24 \mathrm{~h}$ pre-transport. The white blood cell count in the NTG increased during experiment compared to that observed for pre-transport; however, this increase was not significant. The neutrophil numbers of the TG were significantly higher than those of the NTG for each experimental time (Figure 2B).
Additionally, the neutrophil numbers of the TG continuously increased until $2 \mathrm{~h}$ post-transport, and those for transport $4 \mathrm{~h}$ and post-transport $2 \mathrm{~h}$ were significantly $(\mathrm{p}<0.05)$ higher than those of pre-transport. In the NTG, the neutrophil number increased by $18 \%$, while that in the TG increased by $68 \%$.

On the other hand, the lymphocyte number of the TG were higher than those of the NTG for each experimental time except $48 \mathrm{~h}$ post-transport, and there was no significant difference between groups (Figure 2C). However, the lymphocyte number of the TG $\left(5.07 \pm 0.65 \times 10^{3} / \mu \mathrm{L}\right)$ significantly $(\mathrm{p}<0.05)$ increased compared with that of the NTG $\left(3.22 \pm 0.65 \times 10^{3} / \mu \mathrm{L}\right)$ at $48 \mathrm{~h}$ post-transport. Both groups showed no change in lymphocyte numbers during the experimental period compared to that seen at $24 \mathrm{~h}$ pre-transport, respectively. The monocyte numbers in the TG were significantly $(\mathrm{p}<0.05)$ higher than those in the NTG for each experimental time (pre-transport; -24 h, transport; 1, 2, $4 \mathrm{~h}$, and post-transport; 2, 24, $48 \mathrm{~h}$ ) (Figure 2D). In the TG, monocyte numbers at $2 \mathrm{~h}$ post-transport $\left(1.59 \pm 0.29 \times 10^{3} / \mu \mathrm{L}\right)$ were significantly $(\mathrm{p}<$ $0.05)$ higher than those seen at $24 \mathrm{~h}$ pre-transport $(1.08 \pm 0.23$ $\left.\times 10^{3} / \mu \mathrm{L}\right)$. The number of eosinophils in the TG were similar to those of the NTG for each experimental time (Figure 2E). Neutrophil lymphocyte ratios of the TG and NTG were 1.27 to 2.32 and there was no significant difference between the two groups and between $24 \mathrm{~h}$ pre-transport and each experimental time (transport 1, 2, $4 \mathrm{~h}$ and post-transport 2, 24, $48 \mathrm{~h}$ ) in each group (Figure 2F). However, neutrophil-lymphocyte ratios of the TG were $45 \%$ and $46 \%$ higher than those of the NTG at the end of transport $(4 \mathrm{~h})$ and $2 \mathrm{~h}$ post-transport, respectively.

\section{Effects of transport stress on blood parameters in lactating cows}

As shown in Figure 3A, the erythrocyte numbers in the NTG and TG were 6.02 to $6.66 \times 10^{6} / \mu \mathrm{L}$ and 6.15 to $6.53 \times 10^{6} / \mu \mathrm{L}$, respectively during the experiment. There was no significant difference between the two groups and between $24 \mathrm{~h}$ pretransport and each experimental time (transport 1,2, $4 \mathrm{~h}$ and post-transport 2, 24, $48 \mathrm{~h}$ ) in each group. The levels of hemoglobin in the TG (8.64 to $9.44 \mathrm{~g} / 100 \mathrm{~mL}$ ) were a little higher than those in the NTG ( 8.32 to $9.26 \mathrm{~g} / 100 \mathrm{~mL}$ ) at each experimental time (Figure 3B). The hemoglobin levels in the NTG and TG were $8.32 \pm 0.09 \mathrm{~g} / 100 \mathrm{~mL}$ and $8.64 \pm 0.32 \mathrm{~g} / 100 \mathrm{~mL}$ at $2 \mathrm{~h}$ transport, respectively, which were the lowest in the experimental period. However, hemoglobin levels recovered to those of $24 \mathrm{~h}$ pre-transport in both groups after the end of transport. The hematocrit values of the TG were similar those of the NTG at each experimental time (Figure 3C). Furthermore, there was no difference in these values between 24 $\mathrm{h}$ pre-transport and each experimental time (transport 1, 2, $4 \mathrm{~h}$ and post-transport 2, 24, $48 \mathrm{~h}$ ) in each group. In the NTG, the platelet number dramatically increased at $1 \mathrm{~h}$ transport, show- 


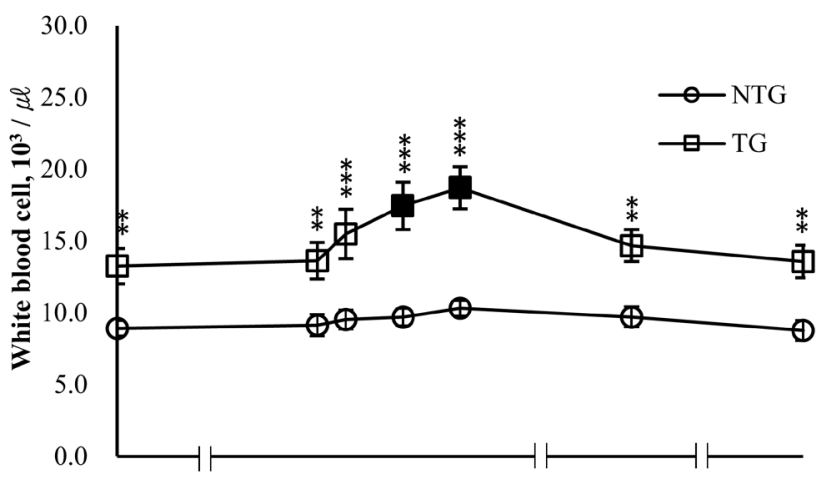

(A)

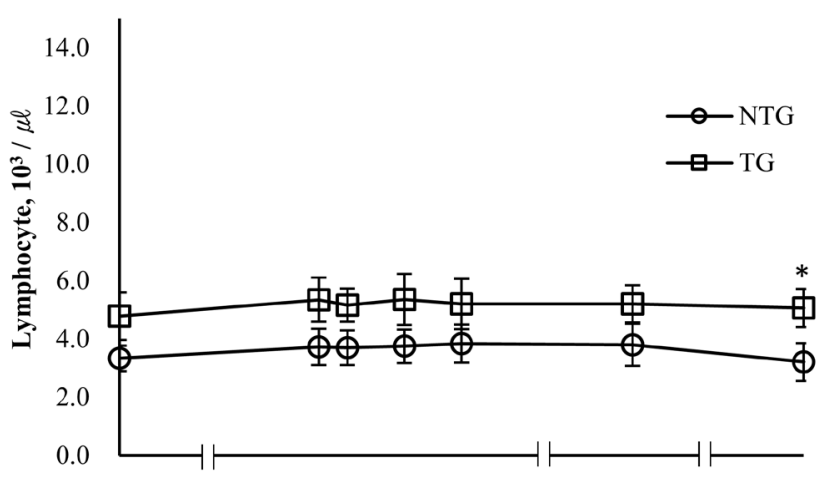

(C)

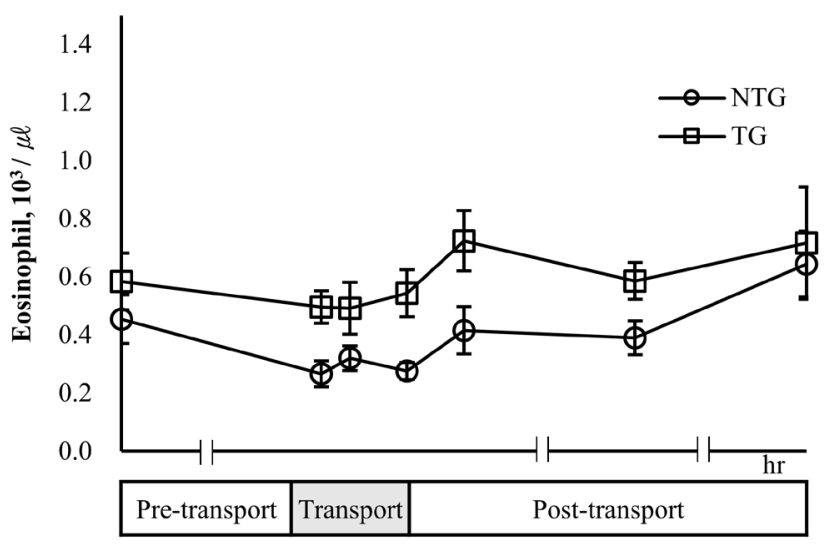

(E)

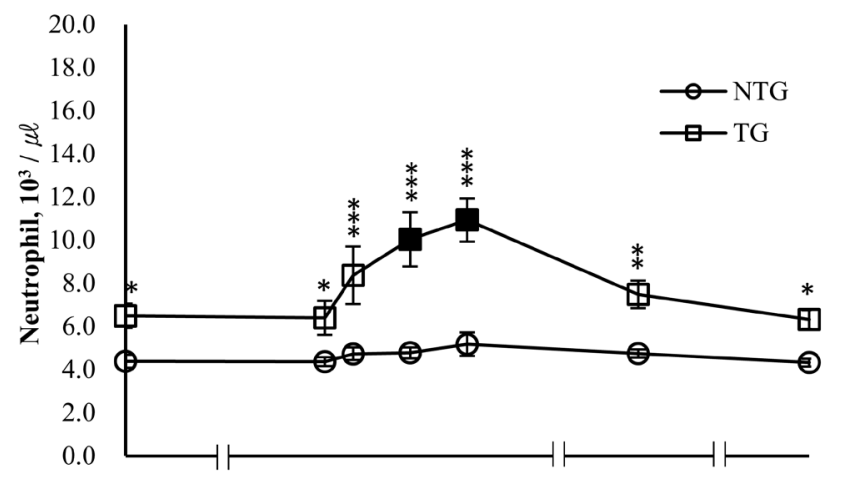

(B)

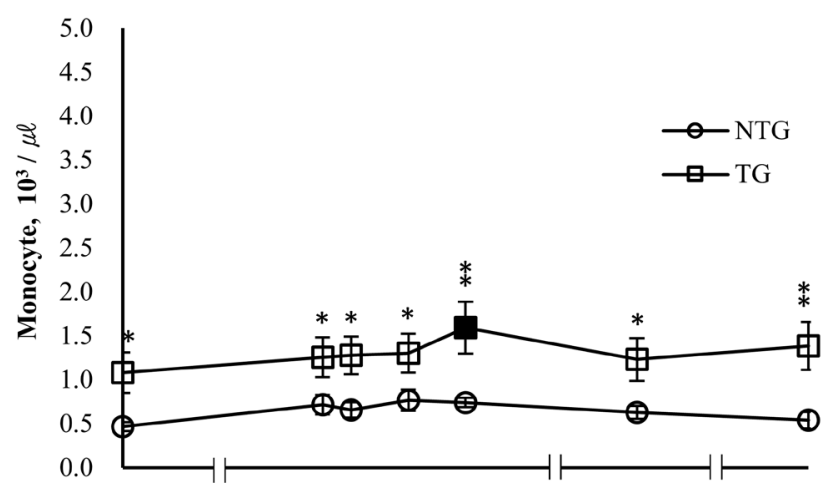

(D)

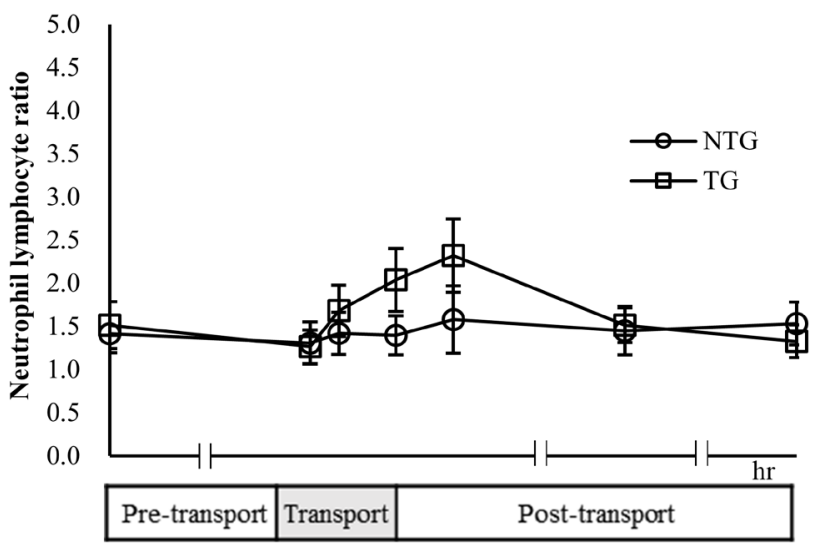

(F)

Figure 2. Effects of transport stress on white blood cell and differential counts in lactating cows. White blood cell count (A), numbers of neutrophils (B), lymphocytes (C), monocytes (D), and eosinophils (E), and neutrophil:lymphocyte ratio (F) were measured for the pre-transport $(-24 \mathrm{~h})$, during transport $(1,2,4 \mathrm{~h})$, and post-transport $(+2$, $+24,+48$ h). NTG, non-transported group; TG, transported group. $\bullet$ : Represent the significant difference $(p<0.05)$ in the data after transport periods compared with pretransport (-24 h). Asterisks mean significant difference between NTG and TG ( $\left.{ }^{*} p<0.05,{ }^{* *} p<0.01,{ }^{* * *} p<0.001\right)$.

ing a significant $(\mathrm{p}<0.05)$ difference compared to that seen at $24 \mathrm{~h}$ pre-transport: $305.60 \pm 43.53 \times 10^{3} / \mu \mathrm{L}$ for the transport $1 \mathrm{~h}$ and $202.60 \pm 28.27 \times 10^{3} / \mu \mathrm{L}$ for the pre-transport $24 \mathrm{~h}$ (Figure 3D). This number decreased after $2 \mathrm{~h}$ transport and was maintained at 246.40 to $259.00 \times 10^{3} / \mu \mathrm{L}$ over time. Also, the platelet number in the TG was $276.40 \pm 43.45 \times 10^{3} / \mu \mathrm{L}$ at $1 \mathrm{~h}$ transport, which was significantly $(\mathrm{p}<0.05)$ approximately $73 \%$ higher than that at $24 \mathrm{~h}$ pre-transport. After $2 \mathrm{~h}$ transport, the platelet number in the TG decreased but then increased significantly $(\mathrm{p}<0.05)$ to about $64 \%$ compared with that of $24 \mathrm{~h}$ pre-transport. However, there was no difference between the TG and NTG at each experimental time.

\section{Effects of transport stress on serum cortisol in lactating cows}

In the TG, a significant $(\mathrm{p}<0.05)$ increase in cortisol concentration was observed during transport and the maximum values were recorded at $2 \mathrm{~h}$ transport $(24 \mathrm{~h}$ pre-transport vs 


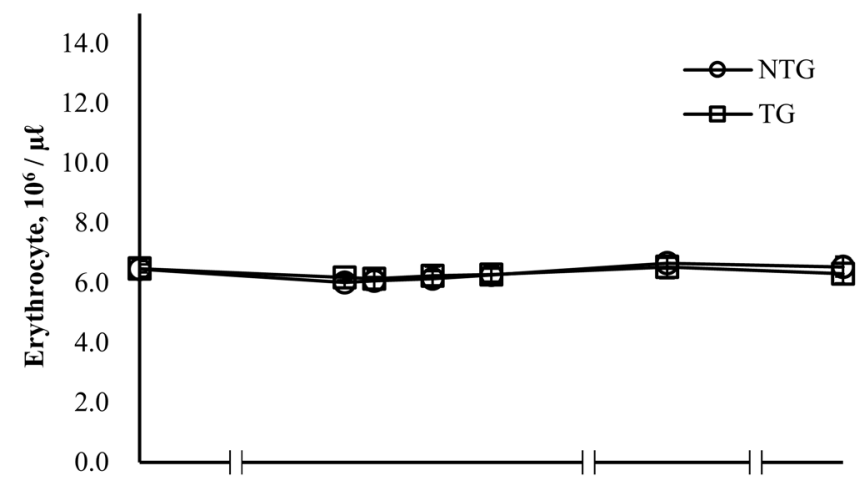

(A)

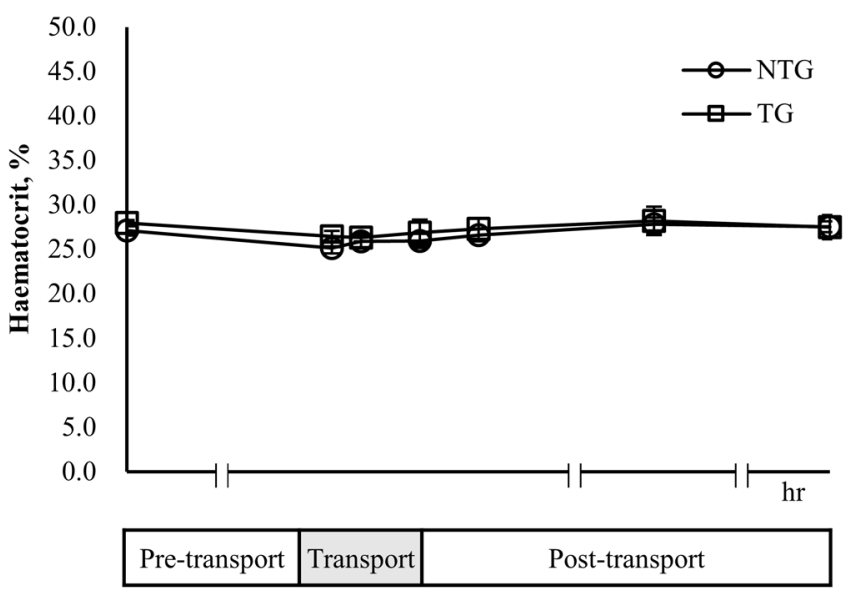

(C)

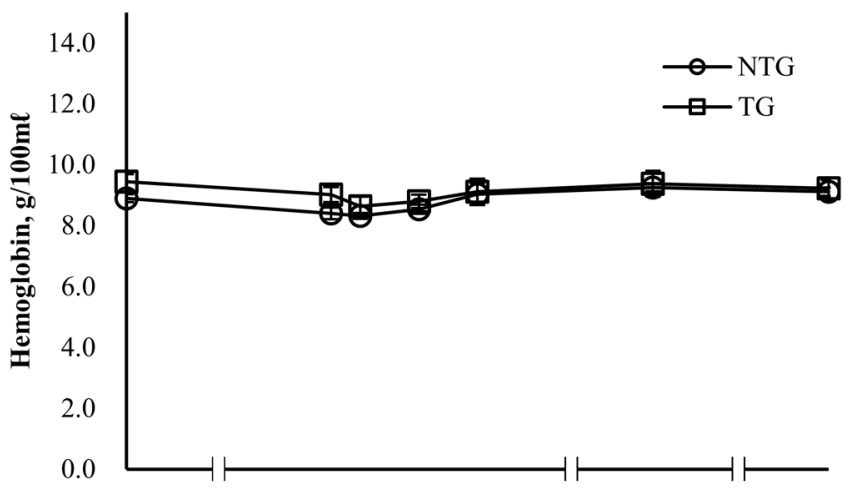

(B)

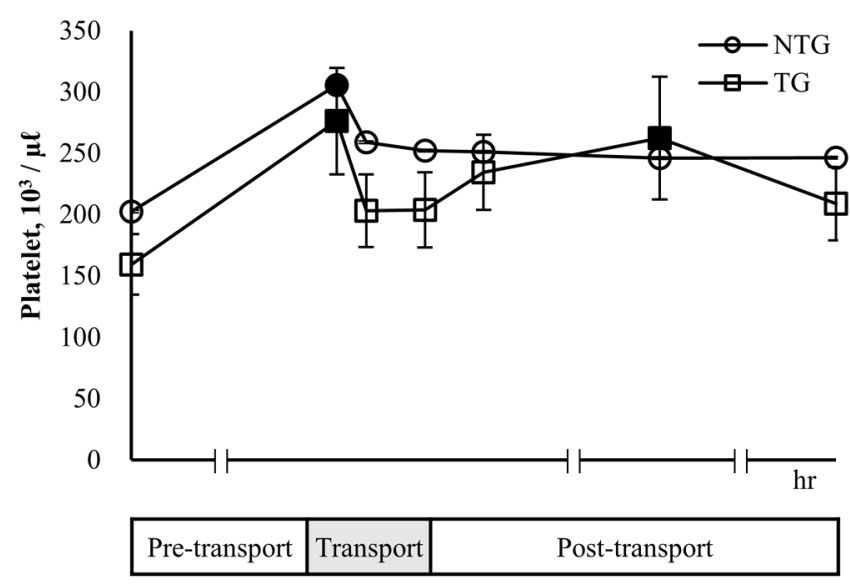

(D)

Figure 3. Effects of transport stress on blood parameters in lactating cows. Erythrocyte (A), hemoglobin (B), hematocrit (C), and platelet (D) were measured for the pretransport $(-24 \mathrm{~h})$, transport $(1,2,4 \mathrm{~h})$, and post-transport $(+2,+24,+48 \mathrm{~h})$. NTG, non-transported group; TG, transported group. $\bullet$ •: Represent the significant difference $(p<0.05)$ in the data after transport periods compared with pre-transport $(-24 \mathrm{~h})$.

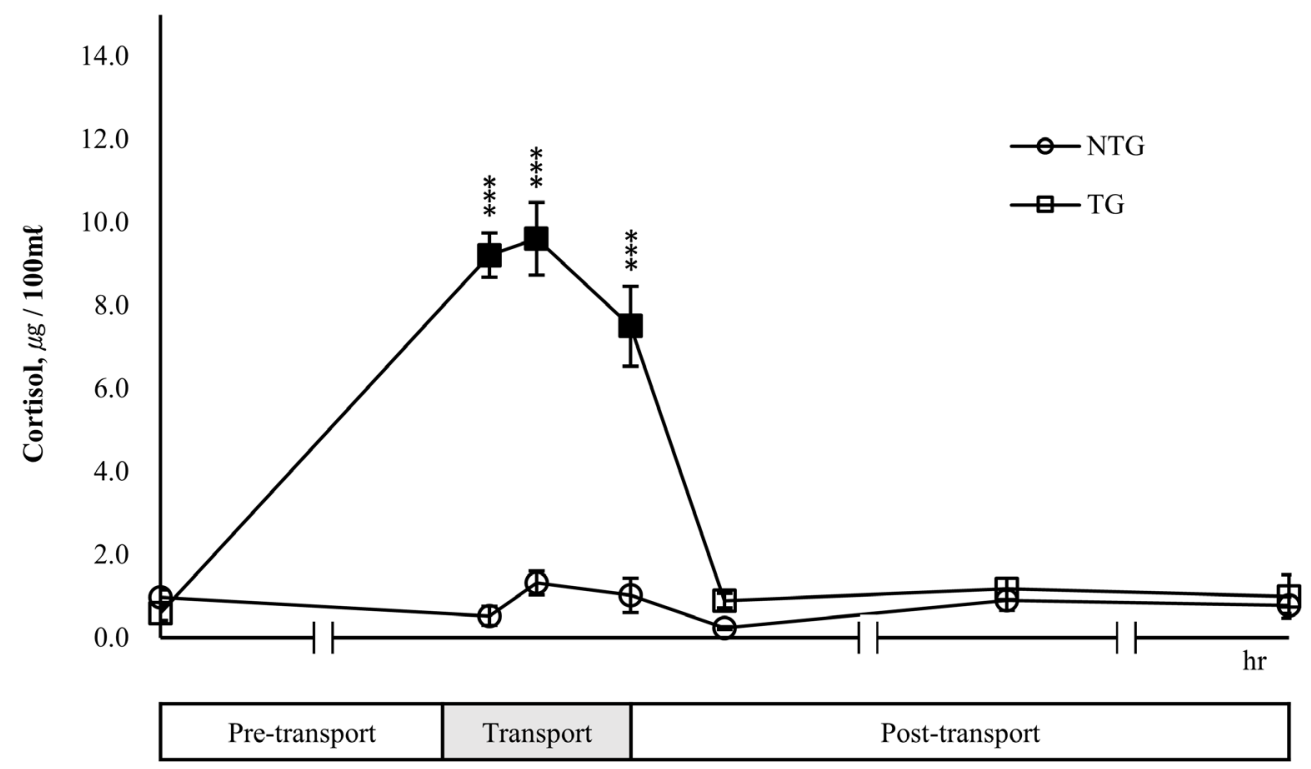

Figure 4. Effects of transport stress on serum cortisol in lactating cows. Serum cortisol was measured for the pre-transport (-24 h), transport (1, 2, $4 \mathrm{~h})$, and post-transport $(+2,+24,+48$ h). NTG, non-transported group; TG, transported group. $\bullet \bullet:$ Represent the significant difference $(p<0.05)$ in the data after transport periods compared with pre-transport $(-24 \mathrm{~h})$. Asterisks mean significant difference between NTG and TG $\left(^{*} p<0.05,{ }^{* \star} p<0.01,{ }^{* *} p<0.001\right)$. 
$2 \mathrm{~h}$ transport $=0.59 \mu \mathrm{g} / 100 \mathrm{~mL}$ vs $9.61 \mu \mathrm{g} / 100 \mathrm{~mL})$ (Figure 4$)$. However, the cortisol levels of the TG decreased to $0.89 \mu \mathrm{g} / 100$ $\mathrm{mL}$ after $2 \mathrm{~h}$ post-transport and then recovering to the level of $24 \mathrm{~h}$ pre-transport. While, there was a slight change in the cortisol concentration of the NTG, there was no significant difference compared to the cortisol levels seen for $24 \mathrm{~h}$ pretransport. During transport, cortisol levels of the TG were 7.50 to $9.61 \mu \mathrm{g} / 100 \mathrm{~mL}$, which were significantly $(\mathrm{p}<0.05)$ higher than those of NTG with 0.53 to $1.32 \mu \mathrm{g} / 100 \mathrm{~mL}$.

Effects of transport stress on daily milk yields and milk

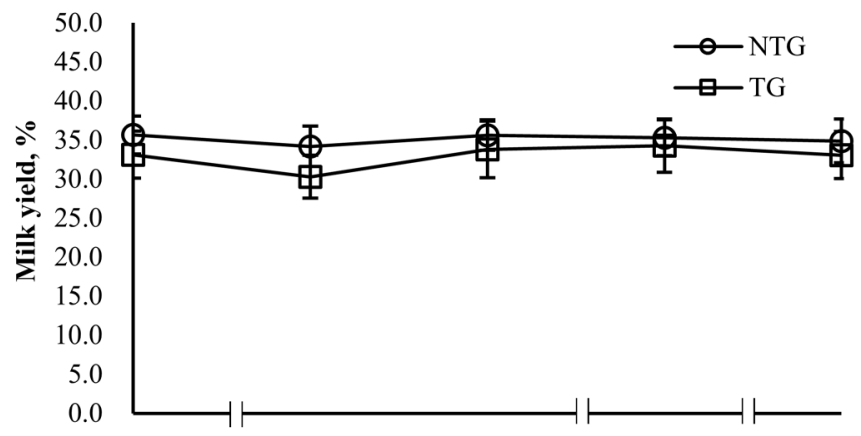

(A)

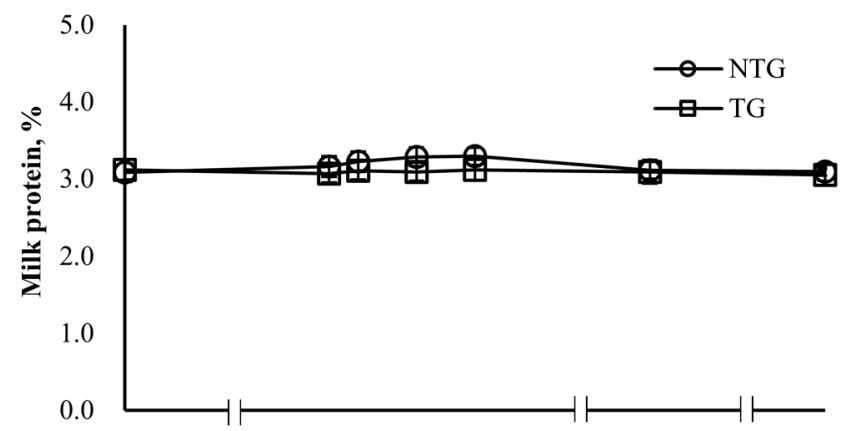

(C)

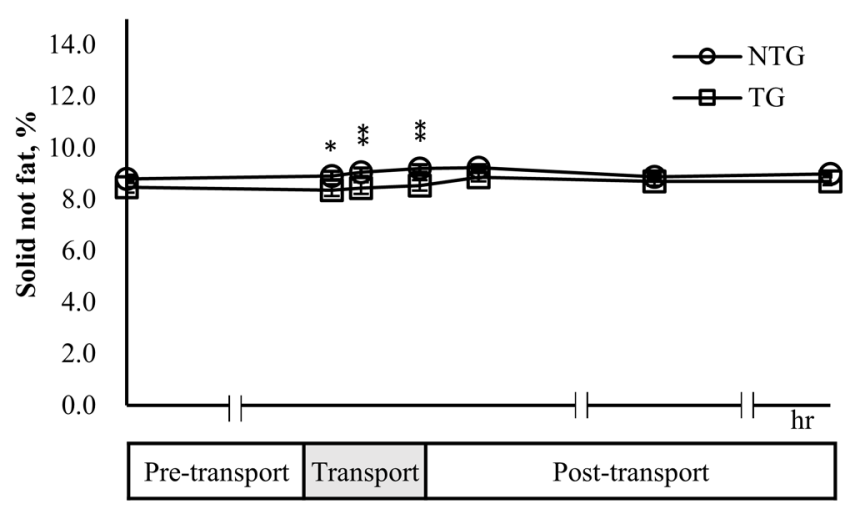

(E)

\section{composition in lactating cows}

Milk yields were measured at $24 \mathrm{~h}$ pre-transport, $0 \mathrm{~h}$ transport, $24 \mathrm{~h}, 48 \mathrm{~h}$, and $72 \mathrm{~h}$, post-transport, respectively (Figure 5A). Milk production in the NTG and TG remained relatively constant during the experiment, but milk yields of the TG were less than those of the NTG. Milk yield of the TG was 30.32 \pm $3.62 \mathrm{~kg} / \mathrm{d}$ at $0 \mathrm{~h}$ transport and a little decreased in comparison with the $24 \mathrm{~h}$ pre-transport. However, this recovered to the level of the $24 \mathrm{~h}$ pre-transport after $24 \mathrm{~h}$ post-transport, i.e., $32.92 \pm 3.01 \mathrm{~kg} / \mathrm{d}$ and maintained to 33.82 to $34.30 \mathrm{~kg} / \mathrm{d}$. To measure the change in milk components due to transport,

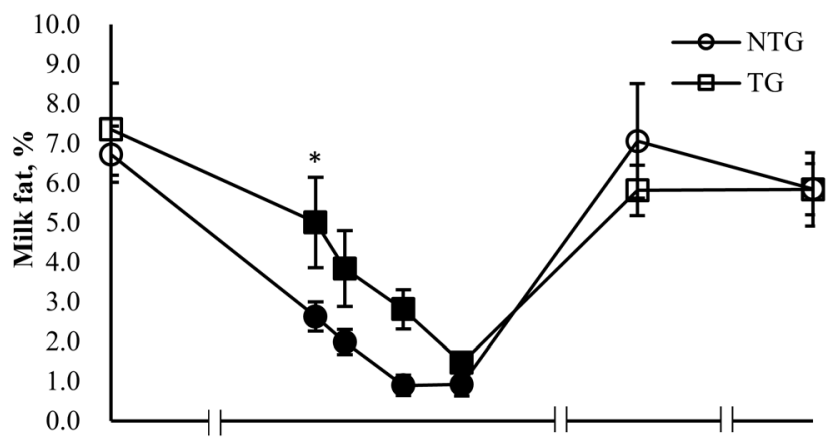

(B)

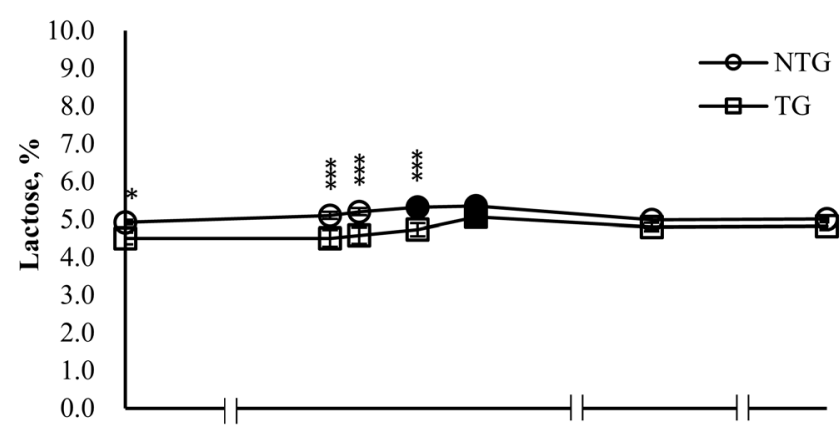

(D)

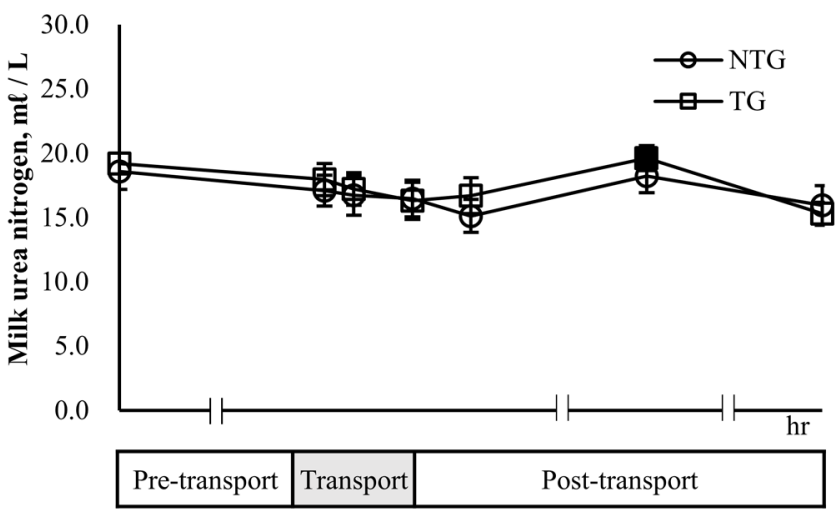

(F)

Figure 5. Effects of transport stress on daily milk yields and milk composition in lactating cows. Milk yield (A) was measured for the pre-transport (-24 h), transport (0 h), and post-transport $(+24,+48,+72 \mathrm{~h})$. Milk fat $(B)$, protein $(C)$, lactose $(D)$, solid-not-fat $(E)$, and milk urea nitrogen $(F)$ were measured for the pre-transport $(-24 \mathrm{~h})$, transport $(1,2,4$ h), and post-transport $(+2,+24,+48$ h). NTG, non-transported group; TG, transported group. $\mathbf{\bullet}$ : Represent the significant difference $(p<0.05)$ in the data after transport periods compared with pre-transport $(-24 \mathrm{~h})$. Asterisks mean significant difference between NTG and TG $\left({ }^{*} p<0.05,{ }^{* *} p<0.01,{ }^{* * *} p<0.001\right)$. 
milk was collected at pre-transport, 1, 2, $4 \mathrm{~h}$ transport, and 2, $4,24,48$, and $72 \mathrm{~h}$ post-transport. During transport and at $2 \mathrm{~h}$ post-transport, the milk fat content of the NTG significantly $(\mathrm{p}<0.05)$ decreased by $60 \%$ to $86 \%$ compared to the $24 \mathrm{~h}$ pretransport, but recovered to the level of $24 \mathrm{~h}$ pre-transport after the $24 \mathrm{~h}$ post-transport (Figure $5 \mathrm{~B}$ ). The milk fat content of the TG significantly $(\mathrm{p}<0.05)$ decreased by $32 \%$ to $80 \%$ compared to that observed for $24 \mathrm{~h}$ pre-transport during the same period and recovered to the level seen for $24 \mathrm{~h}$ pre-transport after $24 \mathrm{~h}$ post-transport. On the other hand, the milk fat content in the TG were higher than those in the NTG during transport and at $2 \mathrm{~h}$ post-transport. In particular, the level of milk fat in the TG at the $1 \mathrm{~h}$ transport was significantly ( $\mathrm{p}<$ 0.05) 1.9 times higher than that in the NTG. The milk protein levels in the NTG were $3.0 \%$ to $3.3 \%$ and those in the TG were $3.0 \%$ to $3.1 \%$; there was no significant difference between two groups and between $24 \mathrm{~h}$ pre-transport and each experimental time (transport 1, 2, $4 \mathrm{~h}$ and post-transport 2, 24, $48 \mathrm{~h}$ ) in each group (Figure 5C). The lactose content in the NTG was $4.93 \% \pm 0.06 \%$ at the $24 \mathrm{~h}$ pre-transport and increased with the initiation of transport (Figure 5D). The lactose content recovered to $4.99 \% \pm 0.08 \%$ at $24 \mathrm{~h}$ post-transport. Especially, the lactose content at $4 \mathrm{~h}$ transport and $2 \mathrm{~h}$ post-transport were $5.32 \% \pm$ $0.09 \%$ and $5.35 \% \pm 0.08 \%$, respectively, which were significantly $(\mathrm{p}<0.05)$ higher than those of $24 \mathrm{~h}$ pre-transport. The lactose levels in the TG showed a similar tendency to those in the NTG. Lactose content in the TG was $5.07 \% \pm 0.13 \%$ at $24 \mathrm{~h}$ post-transport, which significantly $(\mathrm{p}<0.05)$ increased by $12 \%$ compared to that of $24 \mathrm{~h}$ pre-transport. Overall, the lactose content of the TG was a little lower than those of the NTG at each experimental time. However, lactose levels of the TG were significantly $(\mathrm{p}<0.05)$ lower than those of the NTG at $24 \mathrm{~h}$ pretransport and during transport. During transport $(1,2,4 \mathrm{~h})$, solid not fat content of the TG and NTG showed $8.36 \%$ to $8.55 \%$ and $8.92 \%$ to $9.20 \%$, respectively, with levels in the TG being significantly $(\mathrm{p}<0.05)$ lower than those in the NTG (Figure 5E). Furthermore, the levels in the TG and NTG showed no significant difference between the pre-transport $24 \mathrm{~h}$ and each experimental time (transport 1, 2, $4 \mathrm{~h}$ and post-transport $2,24,48 \mathrm{~h}$ ) in each group. Milk urea nitrogen showed no difference between the NTG and TG at each experimental time (Figure 5F). During transport and at $2 \mathrm{~h}$ post-transport, milk urea nitrogen content slightly reduced compared to those of $24 \mathrm{~h}$ pre-transport in both groups, respectively and recovered to the level seen for $24 \mathrm{~h}$ pre-transport and $24 \mathrm{~h}$ post-transport. However, those of the NTG and TG decreased again at $48 \mathrm{~h}$ and $72 \mathrm{~h}$ post-transport, respectively. Particularly, milk urea nitrogen of TG at $48 \mathrm{~h}$ post-transport was significantly $(\mathrm{p}<0.05)$ reduced by approximately $20 \%$ compared to $24 \mathrm{~h}$ pretransport.

Effects of transport stress on milk somatic cell count During transport and at $2 \mathrm{~h}$ post-transport, the SCC of the NTG tended to reduce but sharply increased at $24 \mathrm{~h}$ post-transport (Table 1). Further, these recovered to the levels observed $24 \mathrm{~h}$ pre-transport at $48 \mathrm{~h}$ post-transport. However, the SCC of the TG was significantly $(\mathrm{p}<0.05)$ higher at $1 \mathrm{~h}$ during transport by about 3.6 times than that at $24 \mathrm{~h}$ pre-transport; this then reduced to 128.4 to $173.4 \times 10^{3} / \mathrm{mL}$ after the end of transport (from $2 \mathrm{~h}$ post-transport to $48 \mathrm{~h}$ post-transport).

\section{DISCUSSION}

The present study was performed to investigate the effects of transport stress on physiological and hematological responses and milk performance in lactating dairy cows. Our results demonstrated that transport stress lead to increased leucocyte, neutrophil, and lymphocyte numbers as a result of elevated cortisol levels in lactating cows.

Transport stress is known to lead to increased total leucocyte count and neutrophil, eosinophil, and monocyte count in livestock [11]. In the present study, the total leucocyte, neutrophil, and monocyte numbers in lactating cows transported over $200 \mathrm{~km}$ for $4 \mathrm{~h}$ were significantly higher than those of the NTG at each experimental time. Leukocytes and neutrophil counts of the TG were high both during transport $2 \mathrm{~h}$ post-

Table 1. Changes in somatic cell count of lactating cows pre-, during and post-transport

\begin{tabular}{|c|c|c|c|c|c|}
\hline Time & NTG & $p$ value $^{1)}$ & TG & p value $e^{1)}$ & p value $e^{2)}$ \\
\hline \multicolumn{6}{|c|}{ Somatic cell count, $\times 10^{3} / \mathrm{mL}$} \\
\hline-24 & $76.80 \pm 25.21$ & - & $184.00 \pm 48.15$ & - & 0.5718 \\
\hline 2 & $48.40 \pm 9.50$ & 0.8808 & $438.20 \pm 228.18$ & 0.1820 & 0.0422 \\
\hline 4 & $26.20 \pm 4.68$ & 0.7894 & $305.00 \pm 132.50$ & 0.5235 & 0.1437 \\
\hline+2 & $33.60 \pm 8.52$ & 0.8196 & $128.40 \pm 65.80$ & 0.7692 & 0.6170 \\
\hline+48 & $78.20 \pm 19.55$ & 0.9941 & $138.20 \pm 41.57$ & 0.8090 & 0.7515 \\
\hline
\end{tabular}

\footnotetext{
1) Pre-transport time vs during transport or post-transport time.

${ }^{2)}$ NTG (non-transported group) vs TG (transported group).

Data are represented as mean \pm standard error.
} 
transport. Yagi et al [12] have reported that the increase in leukocyte numbers is due to an increase in neutrophil numbers, which together constitute a high proportion of white blood cells. In addition, glucocorticoids are known to stimulate the inflow of neutrophils into the bone marrow and blood vessels and inhibit their migration to other tissues [13]. Based on the results of the present study, transport stress appears to lead to a 13 to 16-fold higher cortisol concentration than that before transport, resulting in the increase in the number of neutrophils. Seixas et al [14] reported that heat stress promoted the secretion of stress hormones, which led to increased number of leukocytes in Brazilian hair sheep. Our results resemble those of Tarrant et al [15], who he observed that total leukocyte and neutrophils were higher by $23 \%$ to $68 \%$ in Friesian steers after transporting $1,000 \mathrm{~km}$ by an articulated truck for $24 \mathrm{~h}$ than in those before transport. On the other hand, transport did not affect eosinophil numbers in the present study. However, Ali-Gholi et al [16] reported that the number of eosinophils was decreased $3 \mathrm{~h}$ post-transport in hybrid dairy cows transported by truck for a $40 \mathrm{~km}$ round trip. This disparity in the results might be due to differences in transport distance and time.

The neutrophil:lymphocyte ratio is used as a general measure of response to stress. Stress results in a decrease in the number of lymphocytes and an increase in that of neutrophils, leading to an increase in the neutrophil:lymphocyte ratio [17]. Based on the results of the present study, there was little change in the neutrophil:lymphocyte ratio in non-transported cows during the experiment, whereas in transported cows, this ratio was higher by $34 \%$ to $50 \%$ at the end of transport and $2 \mathrm{~h}$ post-transport than that at $24 \mathrm{~h}$ pre-transport, because neutrophils were greatly increased in the same time period. Trucking for $4 \mathrm{~h}$ appears to be stressful to lactating cows. However, the red blood cell count, hemoglobin levels, and hematocrit were not influenced by transport. These results were consistent with those of a study on wild goats transported for 100 minutes [18] and that on Friesian steers transported for $3 \mathrm{~h} \mathrm{[19].}$ In contrast, Earley et al [20] reported that the red blood cell count, hemoglobin level, and hematocrit in Holstein-Friesian bull calves were significantly higher after transporting them for $474 \mathrm{~km}$ by an articulated truck for 8 hours. There was also a significant increase in hematocrit in Holstein steers subjected to $15 \mathrm{~h}$ transport stress [21]. These results were not consistent with our observations. Several experiments have suggested that long-term road transport induces dehydration, leading to decreased plasma volume [19,21-23], and the activation of the sympathetic nervous system by transport stress leads to the contraction of the spleen, causing the red blood cells in the spleen to flow into the blood, thereby increasing the erythrocytes and hematocrit $[24,25]$. The spleen is well known to be an erythrocyte reservoir [26]. In addition, erythropoiesis is regulated by a well-coordinated mechanism to maintain the normal range of red blood cells despite changes in environmental conditions [26]. Therefore, hematocrit appears to be influenced by transport time. However, hematocrit levels may have been maintained during transport in the present study because $4 \mathrm{~h}$ of transport in was probably not sufficient to affect the number of erythrocytes and the spleen in dairy cows. Exposure to a new environment or stress caused by handling or transport affects HPA and promotes the release of glucocorticoids from the adrenal cortex in livestock [27]. In general, the levels of cortisol and catecholamine, a type of glucocorticoids, are widely used as indicators of stress $[27,28]$. In the present study, cortisol secretion was increased sharply as a result of transport stress after the start of transport, and was about 13 to 16 times higher than that $24 \mathrm{~h}$ pre-transport. Cortisol concentration began to decrease after the end of transport and almost recovered to the pre-transport level. These results are consistent with those of Yagi et al [12], who observed that cortisol level peaked at $2 \mathrm{~h}$ during transport and recovered to the pre-transport level at $2 \mathrm{~h}$ post-transport in dairy cows transported for $4 \mathrm{~h}$, and that no change in cortisol concentration was observed in the control group, which was not transported [29]. Similar results have also been obtained in experiments conducted on sheep [30], goats [31,32] and calves [33].

Changes in daily milk yield were investigated once a day from 1 day pre-transport to 3 days post-transport. Milk production of the TG with increased SCC was a little lower than that of the NTG. According to Cinar et al [34], milk SCC affects milk production - milk yield is reduced by increased SCC. This finding was consistent with previously reported results that heat stress decreases milk yield in lactating cows $[35,36]$. Meanwhile, the milk SCC of the TG increased sharply during transport and was higher than that in dairy cows restrained by stanchion throughout the experiment in the present study. These results are similar to those of a previous report stating that SCC was increased when 9 lactating cows were transported for $4 \mathrm{~h}$ [12]. SCC is also the most commonly used indicator of milk quality $[37,38]$. The milk quality of the TG was lowered owing to the elevated SCC caused by transport stress. Milk somatic cells include $75 \%$ leucocytes and 25\% epithelial cells [37]. Therefore, the elevated SCC during transport seems to be influenced by the significant increase in leucocyte number owing to transport stress. After transport, the SCC of the TG decreased to 128 to $174 \times 10^{3} / \mathrm{mL}$ and milk quality improved in a manner similar to that in the NTG. Generally, milk quality is held to be good when milk SCC is less than $200 \times 10^{3} / \mathrm{mL}[37,38]$. In addition, the elevated SCC negatively affected milk constituents because SCC is related to milk quality [34,37]. Protein and solid non-fat levels were not changed during transport in both groups but protein, solid non-fat, and lactose content in the TG was lower than that in the NTG throughout the experiment, and the lactose levels in the TG and NTG increased with the start of transport and restraint, 
respectively. Lactose levels in the NTG recovered to the original level at $24 \mathrm{~h}$ post-transport, whereas lactose levels in the TG recovered at only $72 \mathrm{~h}$ post-transport. However, the milk fat content in the TG was higher than that in the NTG, and milk fat levels of both groups decreased over $4 \mathrm{~h}$ of transport and restraint, respectively. According to Harmon [39], the increased SCC reduces the lactose and fat content of milk by reducing the synthetic activity of the mammary tissue. Some studies, however, have reported no change in fat content [40-42]. The results of this experiment are considered to be accounted for as follows: the decreased fat content of milk is due to the variation among lactating cows rather than the effects on mammary tissue due to elevated SCC.

Taken together, we observed that 4-h transport led to increased plasma cortisol, which was responsible for the effects on some blood parameters-transport stress increased leucocyte, neutrophil, eosinophil, and monocyte numbers. In addition, transport stress may bring about increased milk SCC and decreased milk yield in lactating dairy cows. Therefore, further studies are required to identify measures to mitigate these changes caused by transport stress to improve well-being, health, milk production, and milk quality in lactating dairy cows.

\section{CONFLICT OF INTEREST}

We certify that there is no conflict of interest with any financial organization regarding the material discussed in the manuscript.

\section{ACKNOWLEDGMENTS}

This work was supported by Korea Institute of Planning and Evaluation for Technology in Food, Agriculture, Forestry and Fisheries (IPET) through Advanced Production Technology Development Program, funded by Ministry of Agriculture, Food and Rural Affairs (MAFRA) (116056-03-2-HD020).

\section{REFERENCES}

1. National Research Council. Guidelines for the humane transportation of research animals. Washington DC, USA: National Academies Press; 2006.

2. Fraser AF. The nature of cruelty to animals. Appl Anim Ethol 1979;5:1-4.

3. Lambooij JE, Garssen GJ, Wastra D, Matemarn G, Merkus GSM. Transport of pigs by car for two days: some aspects of watering and loading density. Livest Prod Sci 1985;13:289-99.

4. Brandshaw RH, Parrot RF, Goode JA, et al. Behavioural and hormonal responses of pigs during transport: effect of mixing and duration of journey. Anim Sci 1996;62:547-54.

5. Atkinsson S. Farm animal transport, welfare and meat quality [master's thesis]. Skara, Sweden: Swedish University of Agricultural Sciences; 2000.

6. Ferlazzo A. Large animal transportation procedures in Europe: present and future. Vet Res Commun 2003;27:513-4.

7. Selye $H$. The general adaptation syndrome and the diseases of adaptation. J Clin Endocrinol 1946;6:117-230.

8. Swanson LW, Sawchenko PE. Paraventricular nucleus: a site for the integration of neuroendocrine and autonomic mechanisms. Neuroendocrinology 1980;31:410-7.

9. Fulford AJ, Harbuz MS. An introduction to the HPA. In: Steckler T. Kalin NH, Reul JMHM, editors. Handbook of Stress and the Brain. Amsterdam, the Netherlands: Elsevier; 2005. p. 43-66.

10. Levine S. Stress: An historical perspective. In: Steckler T. Kalin NH, Reul JMHM, editors. Handbook of stress and the brain. Amsterdam, the Netherlands: Elsevier; 2005. p. 3-23.

11. Seo D, Bhuiyan MS, Sultana H, Heo JM, Lee JH. Genetic diversity analysis of South and East Asian duck populations using highly polymorphic microsatellite markers. Asian-Australas J Anim Sci 2016;29:471-8.

12. Yagi $Y$, Shiono $H$, Chikayama $Y$, et al. Transport stress increases somatic cell counts in milk, and enhances the migration capacity of peripheral blood neutrophils of dairy cows. J Vet Med Sci 2004;66:381-7.

13. Bishop CR, Athens JW, Boggs DR, et al. Leukokinetic studies. 13. A non-steady-state kinetic evaluation of the mechanism of cortisone-induced granulocytosis. J Clin Invest 1968;47:24960.

14. Seixas L, de Melo CB, Tanure CB, Peripolli V, McManus C. Heat tolerance in Brazilian hair sheep. Asian-Australas J Anim Sci 2017;30:593-601.

15. Tarrant PV, Kenny FJ, Harrington D, Murphy M. Long distance transportation of steers to slaughter: Effect of stocking density on physiology, behaviour and carcass quality. Livest Prod Sci 1992;30:223-38.

16. Ali-Gholi R, Siamak AR, Daryoush M. Influence of short-term road transport stress on blood parameters in cows. Medycyna Wet 2007;63:1311-5.

17. Dhabhar FS, Miller AH, McEwen BS, Spencer RL. Stress-induce changes in blood leukocyte distribution - role of adrenal steroid hormones. J Immunol 1996;157:1638-44.

18. Lopez O, Marco I, Montane J, Lavin S. Transport stress in Southern chamois (Rupicapra pyrenaica) and its modulation by acepromazine. Vet J 2006;172:347-55.

19. Tadich N, Gallo H, Bustamante H, Schwerter M, van Schaik G. Effects of transport and lairage time on some blood constituents of Friesian-Cross steers in Chile. Livest Prod Sci 2005;93: 223-33.

20. Earley B, Fisher AD, O'Riordan EG. Effects of pre-transport fasting on the physiological responses of young cattle to 8-hour road transport. Irish J Agric Food Res 2006;45:51-60.

21. Warriss PD, Brown SN, Knowles TG, et al. Effects on cattle of 
transport by road for up to 15 hours. Vet Rec 1995;136:319-23.

22. Knowles TG. A review of post transport mortality among younger calves. Vet Rec 1995;137:406-7.

23. Parker AJ, Dobson GP, Fitzpatrick LA. Physiological and metabolic effects of prophylactic treatment with the osmolytes glycerol and betaine on Bos indicus steers during long duration transportation. J Anim Sci 2007;85:2916-23.

24. Mitchell G, Hattingh J, Ganhao M. Stress in cattle assessed after handling, after transport and after slaughter. Vet Rec 1988;123: 201-5.

25. Stewart IB, McKenzie DC. The human spleen during physiological stress. Sports Med 2002;32:361-9.

26. Park SK. An interpretation on abnormal finding of CBC. Korean J Med 2010;78:531-9.

27. Brown EJ, Vosloo A. The involvement of the hypothalamopituitary-adrenocortical axis in stress physiology and its significance in the assessment of animal welfare in cattle. Onderstepoort J Vet Res 2017;84:a1398.

28. Möstl E, Palme R. Hormones as indicators of stress. Domest Anim Endocrinol 2002;67-74.

29. Nanda AS, Ward WR, Dobson H. Effects of naloxone on the oestradiol-induced LH surge and cortisol release in transported cows. J Reprod Fertil 1989;87:803-7.

30. Ali BH, Al-Qarawi AA, Mousa HM. Stress associated with road transportation in desert sheep and goats, and the effect of pretreatment with xylazine or sodium betaine. Res Vet Sci 2006;80:343-8.

31. Tajik J, Nazifi S, Eshtraki R. The influence of transportation stress on serum cortisol, thyroid hormones, and some serum biochemical parameters in Iranian cashmere (Raini) goat. Veterinarski Arhiv 2016;86:795-804.

32. Al-Abry GS, Mahmoud IY, Al-Bahry SN, Mann G. Catechol- amine and cortisol levels in relation to temperature and transportation stress in goats. In: Proceeding of Emerging Trends in Academic Research (ETAR)-2014; 2014 Nov 25-26; Bali, Indonesia.

33. Bernardini D, Gerardi G, Peli A, et al. The effects of different environmental conditions on thermoregulation and clinical and hematological variables in long-distance road-transported calves. J Anim Sci 2012;90:1183-91.

34. Cinar M, Serbester U, Ceyhan A, Gorgulu M. Effect of somatic cell count on milk yield and composition of first and second lactation dairy cows. Ital J Anim Sci 2015;14:3646.

35. Spiers DE, Spain JN, Sampson JD, Rhoads RP. Use of physiological parameters to predict milk yield and feed intake in heatstressed dairy cows. J Therm Biol 2004;29:759-64.

36. Gaafar HMA, Gendy ME, Bassiouni MI, et al. Effect of heat stress on performance of dairy Friesian cow's milk production and composition. Researcher 2011;3:85-93.

37. Sharma N, Singh NK, Bhadwal MS. Relationship of somatic cell count and mastitis: an overview. Asian-Australas J Anim Sci 2011;24:429-38.

38. Hand KJ, Godkin A, Kelton DF. Milk production and somatic cell counts: a cow-level analysis. 2012;95:1358-62.

39. Harmon RJ. Physiology of mastitis and factors affecting somatic cell counts. J Dairy Sci 1994;77:2103-12.

40. Kitchen BJ. Review of the progress of dairy science: bovine mastitis: milk compositional changes and related diagnostic tests. J Dairy Res 1981;48:167-88.

41. Grandin T. Assessment of stress during handling and transport. J Anim Sci 1997;75:249-57.

42. Guo JZ, Liu XL, Xu AJ, Xia Z. Relationship of somatic cell count with milk yield and composition in Chinese Holstein population. Agric Sci China 2010;9:1492-6. 